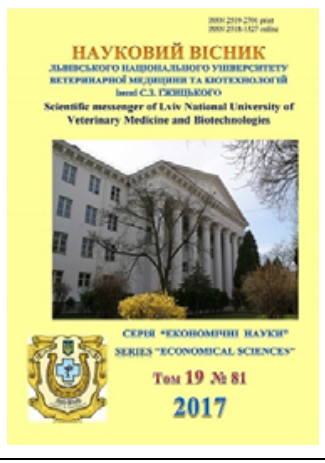

Науковий вісник Львівського національного університету ветеринарної медицини та біотехнологій імені С.З. Гжицького

Scientific Messenger of Lviv National University of Veterinary Medicine and Biotechnologies

doi:10.15421/nvlvet8116

ISSN 2519-2701 print

ISSN 2518-1327 online

$\underline{\text { http://nvlvet.com.ua/ }}$

УДК 330.341.1

\title{
Умови формування інноваційної моделі економічного розвитку економіки України
}

\author{
О.В. Орлова-Курилова \\ pretty_62@ukr.net
}

Луганський національний аграрний університет, м. Харків, Украӥна

вул. Алчевських, 44, м. Харків, 61002, Украӥна

\begin{abstract}
Досліджено умови формування інноваційної моделі економічного розвитку економіки Украӥни. Визначені напрямки державної політики, спрямованої на прискорення інновачійних прочесів. На основі розрахунків доведено, щзо зростання державних витрат на фінансування технічних наук може бути здійснене на основі перерозподілу фінансових ресурсів. Рівень інновачійної активності промислових підприємств України суттєво поступається розвинених країнам ЄС. Особливо критичним є відставання від розвинених країн у реалізачії інноваційних товарів, робіт та послуг, які були новими для ринку. Одним із факторів, який би сприяв посиленню комериіалізаиії науки, повинно стати використання досвіду зарубіжних країн щодо податкового стимулювання впровадження інновачій. Відновлення економічного зростання не супроводжувалося стійкою тендениією до підвищення ефективності технологічних інновачій.

Побудова інновачійної моделі економічного розвитку краӥни потребує мобілізачії фінансових, матеріальних та трудових ресурсів держави. В умовах обмеженості фінансових ресурсів вагомим джерелом збільшення витрат на технічні науки може слугувати їх перерозподіл. 3 метою активізації інноваційної діяльності необхідне впровадження податкове стимулювання зростання інноваиійних витрат. Серед провідних напрямків - впровадження прискорених норм амортизації для інновачійного обладнання.
\end{abstract}

Ключові слова: інновації, інновачійна модель,технологічні інновачії, державна політика.

\section{Conditions of innovational model of Ukrainian economy economic development formation}

\author{
O. Orlova-Kurilova \\ Lugansk National Agrarian University, \\ Alchevskyh str., 44, Kharkiv, 61002, Ukraine
}

The aim of the work is to identify the most urgent problems that restrain the transition of the economy to the principles of the innovative model of economic development, as well as to develop concrete proposals to stimulate innovation activity in the context of its further integration of Ukraine into the world scientific and technical and socio-economic space.

The conditions of formation of an innovative model of economic development of Ukraine's economy were studied in the article. The directions of the state policy directed on acceleration of innovative processes are determined. It is proved, based on calculations, that the increase of state expenditures on financing of technical sciences can be carried out on the basis of redistribution of financial resources.

The level of innovation activity of industrial enterprises of Ukraine is significantly inferior to the developed countries of the EU. The critical lag behind developed countries in the implementation of innovative products, works and services that were new to the market. One of the factors contributing to the increased commercialization of science should be the use of the experience of foreign countries in tax incentives for the introduction of innovations. Restoration of economic growth was not accompanied by a steady tendency to increase the efficiency of technological innovations.

Orlova-Kurilova, O. (2017). Conditions of innovational model of Ukrainian economy economic development formation. Scientific Messenger LNUVMB, 19(81), 93-97. 
The construction of an innovative model of economic development of the country requires the mobilization of the financial, material and labor resources of the state. In the context of the limited financial resources a powerful source of increased costs of technical science can serve their redistribution. In order to stimulate innovation activity, it is necessary to introduce tax incentives for the growth of innovation costs. Among the leading directions is the introduction of accelerated depreciation rates for innovative equipment.

Key words: innovations, innovation model, technological innovations, state policy

\section{Вступ}

Подолання наслідків світових фінансовоекономічних криз та відновлення стійких темпів економічного розвитку буде залишатися однією із найважливіших проблем світової економіки на найближче десятиліття. Особливо гостро постає ця проблема i перед Україною, яка демонструє низькі темпи зростання після глибокої кризи. Сповільнення економічної динаміки розвитку української економіки та нездатність ії вийти на докризові темпи економічного зростання свідчить про вичерпання можливостей зростання на базі діючої експортоорієнтованої економічної моделі, в основу якої покладено розвиток сировинних секторів та секторів 3 низьким рівнем доданої вартості. Вітчизняна промисловість країни не змогла зайняти місце головного двигуна технічних інновацій, що суперечить загальносвітовим тенденціям. Висока залежність національної економіки від зміни попиту на сировинні товари несе в собі постійну загрозу закріплення за Україною сировинного придатку для розвинених країн світу. Актуальність вирішення даної проблеми потребує якнайшвидшої зміни нинішньої моделі економічного зростання, розробки та реалізації національної моделі інноваційного розвитку.

Аналіз останніх досліджень та публікачій. В останні десятиріччя проблеми переходу на інноваційну модель розвитку привертають увагу багатьох українських вчених. Серед робіт варто виділити праці В. Гейця (Heits, 2015), В. Вишневського (Vyshnevskyi et al., 2016), Л. Федулова (Fedulova, 2015), Я. Жаліла, О. Дацій (Datsii et al., 2010), В. Бесадіна (Tkachuk et al., 2014), Н. Краус (Kraus, 2015), О. БондарПідгурської (Bondar-Pidhurska, 2016) та ін. Ряд вчених (В. Інозємцев, В. Мау) виділяють дві моделі інноваційного розвитку національних економік: 1) модель «національних лідерів» або «національних чемпіонів»; 2) модель конкуренції (Inozemcev, 2000; Mau, 2012). Досліджуючи становлення та розвиток інноваційних процесів у різних країнах, Д. Белл (Bell, 1999), Б. Квасюк (Bolkhovytynova et al., 2003), В. Вишневский (Vyshnevskyi et al., 2016) відмічали, що у різних країнах історично склалися історично різні моделі організації інноваційної моделі економічного розвитку. Як зазначали О. Дацій, В. Гаман, Н. Дацій, багато країн орієнтовані переважно на дифузію інновацій (Швеція, Швейцарія) або ж на забезпеченість сприятливості досягнень світового НТП за рахунок розвитку інноваційної інфраструктури й координації розвитку різних секторів науки і технологій (Японія, Південна Корея) (Datsii et al., 2010).

Серед основних «рушійних сил» багато вчених називають наявність потужної науки та освіти, комерціалізацію наукових знань, загострення нецінової конкуренції, поглиблення поділу праці та спеціалізації, захист інтелектуальної власності, розвиток інституційної інфраструктури, державну політику підтримки інновацій та ін. Перераховані ознаки визначають основні характеристики інноваційної моделі розвитку економіки. Ключове значення, як стверджувала Н. Краус, у формуванні інноваційної економіки належить інституційним факторам. Саме інститути, що працюють в сфері інновацій мають значний вплив на економічне зростання» (Kraus, 2015).

Виділення невирішених раніше частин проблеми. Високо оцінюючи здобутки вчених, слід зазначити, що питання створення умов переходу на інноваційну модель економічного розвитку в контексті посилення інтеграційних процесів буде доцільним. Зазначене обумовило потребу дослідження основних факторів прискорення інноваційного розвитку.

Формулювання цілей статті (постановка завдання). Метою роботи $є$ визначення найбільш актуальних проблем, які стримують перехід економіки на засади інноваційної моделі економічного розвитку, а також розроблення конкретних пропозицій щодо стимулювання інноваційної діяльності в умовах іiі подальшої інтеграції України у світовий науково-технічний та соціально-економічний простір.

\section{Результати та їх обговорення}

Необхідність та основні умови переходу української економіки на інноваційну модель розвитку були розроблені вченими ще на початку 2000 -х років. Колективом провідних вчених країни була розроблена «Стратегія інноваційного розвитку України на 2010 2020 роки в умовах глобалізаційних викликів», в рамках якої висвітлені стратегічні перспективи наукового, технологічного та інноваційного розвитку України на період до 2020 року. Як основні науковотехнологічні пріоритети визначалися розвиток наукомістких та високотехнологічних виробництв (літакобудування, суднобудування, фармацевтична промисловість, нанотехнології). Здійснювалися окремі кроки щодо побудови вітчизняної інноваційної системи, зокрема у сфері створення інноваційної інфраструктури. Були створені та розвиваються технологічні парки, венчурні фонди і т. п. Проте більшість стратегічних цілей, поставлених перед країною, досягти не вдалося, структура економіки залишається практично незмінною, а показники інноваційної діяльності демонструють затухаючу динаміку.

Питома вага інноваційної продукції в загальному обсязі промислової продукції в Україні становила 1,4\% проти 9,4\% у 2000 р. і 3,8\% у 2010 р. Кількість підприємств, що впроваджували інновації, залишається незначною і не перевищує 20\% (у 2016 р. - 16,6\%). Тим часом як у багатьох розвинених країнах вона складає 50\% і більше (табл. 1). 
Основні показники інноваційної діяльності промислових підприємств України та країн Свропейського Союзу ${ }^{1}$ у 2015 р.

\begin{tabular}{|c|c|c|c|c|}
\hline Країни & $\begin{array}{c}\text { Сукупний рівень } \\
\text { інноваційної } \\
\text { активності орга- } \\
\text { нізацій }\end{array}$ & $\begin{array}{c}\text { Інтенсивність витрат на } \\
\text { технологічні інновації (пи- } \\
\text { тома вага витрат на техно- } \\
\text { логічні інновації в загаль- } \\
\text { ному обсязі відвантажених } \\
\text { товарів, наданих послуг) }\end{array}$ & $\begin{array}{c}\text { Реалізація інноваційних товарів, } \\
\text { робіт, послуг, які піддалися знач- } \\
\text { ним технологічним змінам або } \\
\text { знов створені товари (в процен- } \\
\text { тах від загального обсягу відван- } \\
\text { тажених товарів, робіт, послуг) }\end{array}$ & $\begin{array}{c}\text { Питома вага інно- } \\
\text { ваційних товарів в } \\
\text { загальному обсязі } \\
\text { відвантажених } \\
\text { товарів, виконаних } \\
\text { послуг } \\
\end{array}$ \\
\hline Україна & 15,2 & 0,7 & 0,4 & 1,4 \\
\hline Німеччина & 67,0 & 2,92 & 10,4 & 13,3 \\
\hline Франція & 56,4 & 2,29 & 8,8 & 6,2 \\
\hline Польща & 21,0 & 1,55 & 3,6 & 2,9 \\
\hline Італія & 23,5 & 1,33 & 4,8 & 10,1 \\
\hline
\end{tabular}

Джерело: (Gorodnikova et al., 2017; Statystychnyi zbirnyk, 2016).

Як свідчать дані, рівень інноваційної активності промислових підприємств України суттєво поступається розвиненим країнам ЄС. Особливо критичним є відставання від розвинених країн у реалізації інноваційних товарів, робіт та послуг, які були новими для ринку.

Технологічна революція, яка спрямована на підвищення ролі ресурсозбе-реження, різко посилює невизначеність в розвитку України, основу спеціалізації якої на міжнародних ринках становить експорт сировинної продукції. Зниження матеріало- та металомісткості продукції, поява штучних та синтетичних матеріалів може призвести до зниження попиту на ключові сировинні товари українського експорту, скорочення надходжень фінансових ресурсів, необхідних для модернізації виробничого потенціалу національної економіки. Все це потребує розробки заходів щодо переходу на інноваційну модель розвитку економіки країни.

Інноваційна модель має «рушійні сили», які можна об’єднати в окремі групи. Серед них можна виділититакі.

По-перше, необхідною передумовою переходу економіки на інноваційну моделі розвитку є прискорення і розвиток науки. В розвинених країнах світу та у країнах, що розвиваються, видатки на науку - в числі пріоритетів, обсяг яких постійно зростає. На жаль, в Україні розвиток науки не є стратегічним пріоритетом державної інноваційної політики. За даними Державної служби статистики, кількість пра-

цівників наукових організацій за 2010-2016 рр. скоротилася на 46,3\%, в тому числі дослідників - 47,6\%. Середня заробітна плата осіб, які займаються науковими дослідженнями і розробками, у 2015 р. становила 4972 грн, або 57,8\% від середньомісячної заробітної плати працівників фінансового сектору. Низький рівень заробітної плати не стимулює оновлення кадрів. Як наслідок, вік значної частини дослідників та вчених становить 60 років та більше. Незважаючи на законодавче встановлення мінімальних державних витрат на фінансування наукових та технічних робіт на рівні 1,7\% ВВП (згідно зі ст. 34 Закону України «Про наукову та науково-технічну діяльність»), фактичний їх розмір за останні десятиліття не перевищував 1\%. Водночас неефективною є структура витрат на дослідження та розробки. Як свідчать дані, прискореними темпами зростали державні видатки на фінансування гуманітарних та суспільних наук, що не відповідає сучасним тенденціям розвитку інноваційних процесів. Так, за 2005-2015 рр. витрати державного бюджету на юридичні науки зросли в 4,9 раза, тимчасом як на технічні науки - лише на 67,6\%. Такі зміни не відповідають тенденціям комерціалізації науки, які характерні для розвинених країн світу.

В умовах обмеженості фінансових ресурсів збільшення державних витрат на фінансування технічних наук повинно здійснюватися за рахунок уповільнення зростання витрат на гуманітарні та суспільні науки (табл. 2).

Таблиия 2

Джерела збільшення державних витрат на технічні та фундаментальні науки

\begin{tabular}{|c|c|c|c|c|c|}
\hline Показники & & 2009 p. & $2015 \mathrm{p}$. & $\begin{array}{c}2015 \text { p. } \\
\text { в \% до } 2009 \text { p. }\end{array}$ & $\begin{array}{c}\text { Середньо-річні } \\
\text { темпи приросту, \% }\end{array}$ \\
\hline A & Б & 1 & 2 & 3 & 4 \\
\hline $\begin{array}{l}\text { Витрати на суспільні та гуманітарні науки за раху- } \\
\text { нок бюджету, млн грн } \\
\text { Темп зростання витрат на наукові та науково- } \\
\text { технічні роботи за рахунок бюджету, \% }\end{array}$ & 1 & 450,4 & $\begin{array}{c}628,1 \\
-\end{array}$ & 139,5 & 5,7 \\
\hline $\begin{array}{l}\text { Витрати на суспільні та гуманітарні науки за раху- } \\
\text { нок бюджету, які необхідні для збереження пи- } \\
\text { томої ваги, яка склалася в } 2009 \text { р., млн грн } \\
\text { (с. } 3, \text { гр. } 1 \text { с с. } 2, \text { гр. } 3 \text { ) } \\
\text { Перевищення фактичних витрат в } 2015 \text { р. над вели- } \\
\text { чиною, яка необхідна для збереження їі питомої } \\
\text { ваги, яка склалася в } 2009 \text { р., млн грн (поле для } \\
\text { маневру, с. 1-3) }\end{array}$ & 3 & 450,4 & 569,3 & 126,4 & 3,9 \\
\hline
\end{tabular}

Джерело: розрахунки автора. 
Таким чином, в умовах значних обсягів дефіциту бюджету, посилення кризових явищ в економіці держава повинна збільшити надходження коштів в сектори, які будуть генерувати в майбутньому доходи, що може бути забезпечене на основі перерозподілу фінансових ресурсів. Уповільнення темпів зростання фінансування державою гуманітарних та суспільних наук дозволить вивільнити значні фінансові ресурси, які можуть бути спрямовані в пріоритетні сфери наукової діяльності.

По-друге, особливістю сучасного розвитку інноваційної моделі у розвинених країнах світу є поглиблення інтеграційних процесів у сфері науки та наукових досліджень. Нині значна частина наукових досліджень та розробок проводиться у кооперації з іншими країнами. Більше того, нині практично не має жодної розвиненої країни, яка б вела самостійно наукову та технічну діяльність за усіма напрямками. Так, наприклад, у Бельгії питома вага організацій, які брали участь у спільних проектах з виконання досліджень і розробок, в загальній чисельності організацій, що здійснювали технологічні інновації, у 2015 р. становила $38,9 \%$, у тому числі з країнами $\mathrm{CC}-27,9 \%$, зі США - 7,3\% (Gorodnikova et al., 2017). Аналогічне спостерігається в інших країнах. Особливо виділяються країни Східної Свропи, де рівень спільної діяльності при здійсненні наукових розробок та досліджень сягає понад 50\%.
В Україні спостерігається уповільнення міжнародної діяльності у сфері науки та технічних розробок. Зменшується чисельність працівників, за межі України, в тому числі на/для проведення наукових досліджень. Якщо у 2014 р. 3 метою проведення досліджень виїхало 3335 осіб, то у 2014 р. - 3641 особа (у 2010 p. - 5391 особа).

3 метою активізації міжнародної діяльності у проведенні наукових та дослідницьких робіт доцільно було б надати пільги підприємницькому сектору при сплаті податку на прибуток. Це може бути зменшення бази оподаткування на величину витрат при проведенні наукових та дослідницьких робіт. Загальна сума пільг може бути визначена шляхом добутку загального обсягу витрат на проведення наукових та дослідницьких робіт на коефіцієнт (розмір може скласти 5 або 10\%).

По-третє, потужний науково-технічний потенціал $\epsilon$ необхідною, але недостатньою умовою для успішного переходу на інноваційну модель розвитку та забезпечення економічної безпеки. Важливо досягти повної і ефективної реалізації цього потенціалу, тобто забезпечити високий рівень комерціалізації нових знань. Інноваційний розвиток та підвищення конкурентоспроможності національної економіки можливі лише за умови високого рівня впровадження результатів у господарську діяльність.

Суттєвим недоліком української науки є слабка орієнтація на інноваційний розвиток (табл. 3).

Таблиия 3

Рівень впровадження результатів інноваційної діяльності за 2010-2015 рр.

\begin{tabular}{|c|c|c|c|c|c|c|}
\hline \multicolumn{1}{|c|}{ Показники } & 2010 p. & 2011 p. & 2012 p. & 2013 p. & 2014 p. & 2015 p. \\
\hline $\begin{array}{l}\text { Рівень впровадження нових технологі- } \\
\text { чних процесів, \% } \\
\begin{array}{l}\text { Рівень освоєння нових видів продукції, } \\
\%\end{array}\end{array} \quad 35,6$ & 47,1 & 43,7 & 31,5 & 54,5 & 39,7 \\
\hline
\end{tabular}

Розраховано по: Statystychnyi zbirnyk, 2016: http:/www.ukrstat.gov.ua.

Як свідчать розрахунки, суттєвого розширення масштабів освоєння нових видів продукції не відбулося. За 2010-2015 рр. рівень освоєння нових видів продукції не перевищував 50\% (в 2014 р. - 30,1\%). Низький рівень впровадження результатів інноваційної діяльності в Україні виступає фактором, який стримує забезпечення економічної безпеки шляхом інноваційного розвитку.

Одним із факторів, який би сприяв посиленню комерціалізації науки, повинно стати використання досвіду зарубіжних країн щодо податкового стимулювання впровадження інновацій. 3 цією метою, на нашу думку, доцільно було б внести зміни до Податкового кодексу України щодо стимулювання збіль- шення витрат на інновації. Це може бути надання підприємствам податкового кредиту на розмір інноваційних витрат на купівлю технологій, обладнання. Можливе застосування прискореної амортизації для окремих видів основних засобів. Мова йде про активну частину основних засобів (групи 4-6). Крім того, доцільно було б знизити ставку податку на додану вартість для нового обладнання, яке ввозиться в Україну. Це дало б змогу зменшити видатки підприємств та підвищити ефективність інноваційної діяльності.

Недостатній рівень інноваційної активності посилюється низькою віддачею від реалізації технологічних інновацій (табл. 4).

Обсяг інноваційної продукції на 1 грн технологічних інновацій

\begin{tabular}{|c|c|c|c|c|c|}
\hline \multicolumn{1}{|c|}{ Показники } & $2011 \mathrm{p}$. & $2012 \mathrm{p}$. & $2013 \mathrm{p}$. & $2014 \mathrm{p}$. & $2015 \mathrm{p}$. \\
\hline $\begin{array}{l}\text { Обсяг інноваційних товарів, робіт, послуг: } \\
\text { в діючих цінах, млн грн } \\
\text { на гривню затрат на тех-нологічні інно- } \\
\text { вації, грн }\end{array}$ & 42386,7 & 36157,7 & 35862,7 & 25669,0 & 23050,1 \\
\hline
\end{tabular}

Розраховано по: Statystychnyi zbirnyk, 2016 
Так, в 2011 р. обсяг інноваційної продукції, одержаної на 1 грн технологічних інновацій, скоротився в 1,8 раза порівнянно з попереднім роком. Лише в 2013 p. спостерігається поліпшення рівня ефективності використання технологічних інновацій та досягнення рівня 2010 р. Таким чином, відновлення економічного зростання не супроводжувалося стійкою тенденцією до підвищення ефективності технологічних інновацій.

\section{Висновки}

Побудова інноваційної моделі економічного розвитку країни потребує мобілізації фінансових, матеріальних та трудових ресурсів держави. В умовах обмеженості фінансових ресурсів вагомим джерелом збільшення витрат на технічні науки може слугувати їхній перерозподіл. 3 метою активізації інноваційної діяльності необхідно впроваджувати податкове стимулювання зростання інноваційних витрат. Серед провідних напрямків - впровадження прискорених норм амортизації для інноваційного обладнання.

\section{Бібліографічні посилання}

Heits, V.M. (2015). Innovatsiina Ukraina 2020: natsionalna dopovid. NAN Ukrainy. K (in Ukrainian).

Vyshnevskyi, V.P., Zbarazska, L.O., Zanizdra, M.Yu., Chekina, V.D. (2016). Natsionalna model neoindustrialnoho rozvytku Ukrainy: monohr. NAN Ukrainy, In-t ekonomiky prom-sti. Kyiv (in Ukrainian).

Fedulova, L.I. (2015). Tekhnolohichna polityka: hlobalnyi kontekst ta ukrainska praktyka: monohrafiia. Kyiv. nats. torh.-ekon. un-t (in Ukrainian).

Innovatsiinyi rozvytok promyslovosti yak skladova strukturnoi transformatsii ekonomiky Ukrainy (2013). K.: NISD (in Ukrainian).

Datsii, O.I., Haman, M.V., Datsii, N.V. (2010). Innovatsiina model rozvytku ekonomiky Ukrainy $\mathrm{v}$ umovakh hlobalizatsii [Tekst] : monohrafiia. Donetsk: Yuho-Vostok (in Ukrainian).

Tkachuk, I.V., Berzhanir, A.L., Tsyhaniuk, A.V. (2014). Innovatsiina model rozvytku: tendentsii ta perspektyvy ekonomichnoi transformatsii: kol. Monohrafiia. Uman. derzh. ped. un-t im. P. Tychyny, N.-d. ekon. in-t. - Uman : Zhovtyi (in Ukrainian).

Kraus, N.M. (2015). Stanovlennaia innovatsiinoi ekonomiky v umovakh instytutsiinykh zmin: monohrafiia. Derzh. navch-nauk. ustanova «Akademiia fin. upr-ya». NDI finans. in-t. Kyiv: Tsentr uchbovoi literatury (in Ukrainian).

Bondar-Pidhurska, O.V. (2016). Naukovo-metodychni zasady staloho innovatsiinoho sotsialno oriientovanoho rozvytku ekonomiky: monohrafiia.. Vyshch. navch. zakl. Ukoopspilky «Poltav. un-t ekonomiky i torhivli (PUET)». Poltava; PUET (in Ukrainian).

Inozemcev, V.L. (2000). Sovremennoe postindustrial'noe obshhestvo: priroda, protivorechija, perspektivy. M.: Logos (in Russian).

Mau, V.A. (2012). Ekonomika i politika v 2011 godu: global'nyj krizis i poisk novoj modeli rosta. Voprosy jekonomiki. 2, 6-14 (in Russian).

Bell, D. (1999). Grjadushhee postindustrial'noe obshhestvo. Opyt social'nogo prognoshhirovanija. M.: «Academia» (in Russian).

Bolkhovytynova, O.Yu., Kvasiuk, B.Ye. , Kirieiev, S.I., Lunina, I.O., Marienko, A.M. (2003). Rol derzhavy u dovhostrokovomu ekonomichnomu zrostanni. Kh.: Fort (in Ukrainian).

Gorodnikova, N.V., Gohberg, L.M., Ditkovskij, K.A. (2017). Indikatory innovacionnoj dejatel'nosti: 2017 : statisticheskij sbornik. Nac. issled. un-t «Vysshaja shkola jekonomiki». M.: NIU VShJe (in Russian).

Statystychnyi zbirnyk (2016). Naukova ta innovatsiina diialnist Ukrainy za 2015 rik. Derzhavna sluzhba statystyky Ukrainy. K. (in Ukrainian).

Received 15.09.2017

Received in revised form 13.10.2017

Accepted 16.10.2017 